\title{
Socio-economic Impact of Women Entrepreneurship in Bangladesh
}

\author{
Neaz Ahmed \\ Department of Social Work, Shahjalal University of Science and Technology, Bangladesh
}

Copyright $\subseteq 2018$ by authors, all rights reserved. Authors agree that this article remains permanently open access under the terms of the Creative Commons Attribution License 4.0 International License

\begin{abstract}
This paper aims at understanding about the socio-economic impact of women entrepreneurship in Bangladesh. Though Bangladeshi women are entering into business sector, they continue to remain vulnerable and marginalized. One of the indications of their marginalization is lack of information and statistics about the situation of women entrepreneurs. This study was therefore carried out focusing on socio-economic impact on entrepreneurship over women lives. For this, exploratory and qualitative research approaches were adopted. All female entrepreneurs of handloom industry in Sylhet City Corporation of Bangladesh were considered as population and data were collected from the purposive sampling method from the population using in-depth interview schedule. Results indicate that their values and reputations have gained betterment along with their business. Nonetheless, these women had to face a number of difficulties while trying to set up their work such as finding a place to open a shop in the market. Market authorities do not believe in women's efficiency, so do the banks. It is difficult for the women entrepreneurs to manage loans from the banks. Most of the respondents had said that they do not face any complications performing their roles as spouse, parents, or homemaker while running the business. Most of the time, their husbands, or other family members encourage them to start and continue a business. After starting the business, most women feel that their status has risen not only within the family but also within the society. Now they enjoy freedom and also contribute economically and to family decision making.
\end{abstract}

Keywords Handloom, Women, Entrepreneurs, Empowerment, Sylhet, Bangladesh

\section{Introduction}

Bangladesh is a resource limited and overpopulated country where total population was estimated 142319000 . Here, the society is highly stratified; gender, class, and location determine services and opportunities. Women are about half of the formal and informal labor force and thus, half of our development depends on them. The total enumerated population comprising of 71255 thousand males and 71064 thousand females which yields a sex ratio of 100.3 indicating equal number of men and women in the country (BBS) [1]. For the functioning of our body, every part of it has to conduct properly. Likewise, for the prosperity of a country, the human resources have to work together which includes both male and female. Participation of women in the country's economic affairs remains necessary. Active participation of women can bring mobility in growth and ensure development process. This research aims to examine the socio-economic impact of women entrepreneurship in Sylhet City of Bangladesh. Engaging in entrepreneurship provides women a platform of income generation, to uplift their social status, works against existing gender biasness and contribute for the betterment of the society.

Articles 28(1) and 28(2) of the Constitution of Bangladesh grant equal rights to women and men in all spheres of public life. Article 10 of the constitution obligates the state to ensure women's active and meaningful participation in all spheres of public life. Bangladesh is also one of the countries that ratified the United Nations (UN) Convention on the Elimination of all Forms of Discrimination against Women (CEDAW). In response to international concerns and constitutional commitments, the Government of Bangladesh has initiated some institutional measures for the enhancement of women's economic position and status in society (Government of Bangladesh (GoB) [2]. The major initiatives undertaken by the Government so far include the establishment of a separate ministry on women's affairs, the formulation of the National Policy for Advancement of Women in 2008, and the National Action Plan (which was prepared in response to the Beijing Platform for Action). The Government has also formed a National Women Small and Medium Enterprise (SME) Forum under the SME Foundation of the Ministry of Industry to promote women's participation in formal economic sectors. 
Bangladesh's Poverty Reduction Strategy Paper (PRSP) [3] which is now the main document for Bangladesh's national development also incorporated some noteworthy issues to ensure women's participation in social and economic life. The industrial and SME policies of 2005 have emphasized women entrepreneurship development, particularly in the SME sector \{Bangladesh Women Chamber of Commerce and Industry (BWCCI) [4].

Publicity of women's products is undertaken through advertisements, brochures, banners and leaflets (www.ecdo-bd.org). Hand weaving has now emerged through women, and handloom products, textiles, and saris are now woven and marketed by women in Manipur Women of Sylhet City, thus, preserving the age-old traditions and weaving procedures. Nakshi Kantha, embroidered by women tell the tales of the past or the women's thinking, incidents, stories of lives, which remain as memoirs for them stitched in with colorful thread to preserve their untold stories, incidents, or thoughts. Most of these designs are stitched without any design printed on the cloth, since the rural women stitch during their spare time on their own and enjoy their endeavor as they stitch designs or subjects of their untold stories on cloth with simple "running stitches".

Innovations in designs are constantly kept in focus to attract buyers with new and innovative ideas and shapes. Designs differ in urban and rural areas along with color, shape, utility, and fashions. Tastes differ in every area. Urban users prefer modernity and sophistication while rural people still cling to and preserve the old culture with traditional values and designs. In fact modernity enters into urban life both in men and women. It has developed as a result of the interplay of a number of institutional dimensions, namely, capitalism, industrialism, surveillance and information control of the nation-state, and development of military power. According to Giddens [5] grasping the complexity of this interplay is essential for a new sociological theory that wants to comprehend our society. The modern society can be distinguished from the pre-modern society on several counts. Modern society is much more dynamic compared to the pre-modern society. In the modern society, pace, intensity and scope of change are greater. Another important feature is the type and nature of modern institutions. Thinking the notion of Giddens women in Bangladesh have accustomed with the culture of modernity.

Modernity changes the trends in the dressing of women in Bangladesh. Fashion in Bangladesh changes from time to time, season to season while trying to maintain the pace and the fashion styles of both developed and developing countries including India. Dressing style of women in Indian subcontinent is quite similar. Sari and Salwar-kamiz are the common outfits for women in this part of the world. In recent years, both women and men of Bangladesh have become very innovative and fashion conscious. Now they tend to wear dresses according to latest trends, western fashions in addition to design and fashions developed in Bangladesh. This is reflected in the different designs and patterns in saris, dresses, tops, gowns as well as designer dresses worn in Bangladesh as a part of Bangladeshi fashions. Therefore the entrepreneurs have to go with the trends and introduce innovative products to attract the eyes of the customers. Very few children prefer the traditional wooden dolls, long-eared elephants, and horses on the wheels, instead they prefer electronic games, digital dolls bearing modern and innovative designs.

Woodcrafts usually by men are also made by women now but in smaller sizes. Similarly, are the situation of the bamboo baskets, fans, trays and bowls which have been preserved through generation? Marma women of the tribal community are still active with their bamboo products, since bamboo clusters still exist in these localities. Though export orders remain for these bamboo items, lack of raw material prevents regular export supply. New areas for business have emerged with training, business meets, foreign trade participation. Women have ventured to produce items previously manufactured only by men. These include manufacture of cosmetics, ready-made garments, preserved food, packaging, printing, batik works, wax items, wood crafts, bamboo works etc. Dress making, embroidery, boutique-shop ownership, cut-piece sales are popular among the women and many have turned into international fashion designers, having graduated in these subjects. Block printing, batik works, dress paintings are popular among the teen-agers (www.thedailystar.nt). Woodcrafts, wax items, batik works, block printing, embroidery etc. are new areas of business for women. By working on them, many women have started their own business. These works have introduced many new sectors of business to the women entrepreneurs

Today, hundreds of women entrepreneurs in SME have emerged successful in their ventures and have built up their business with patience and perseverance. They are earning successfully, providing products with care and concern, and assisting in the economic development of the nation. SMEs, through cultural heritage, can be carried down through generations and become a pivotal issue for the nation. Women in SME have held the flag high with their courage and unending attempts to achieve accomplishments. We salute these fearless women who have emerged as torch-bearers of triumph to initiate and encourage others to follow to a successful life in the SME world (Ethnic Community Development Organization).

Women entrepreneurship has been playing a pivotal role in terms of economic growth, employment generation and industrialization. Although the role of women entrepreneurship is different at different stages of economic development, their role is particularly important for developing countries. Bangladesh Women Chamber of Commerce \& Industry (BWCCI) is the first chamber of 
commerce in the country exclusively working on women's economic and social empowerment in Bangladesh. It is a non-profit, non-political organization established in June 2001 with an enlightened aim to encourage and strengthen women's participation in the private sector as entrepreneurs through promoting a women friendly business environment. BWCCI is a strong community voice, lobbying for micro to macro women entrepreneurs to assist their growth and to improve their social and economic prospects. The members of BWCCI are from the entire range of socio-economic spectrum.

Holt [6] finds the term entrepreneur may be properly applied to those who incubate new ideas, start enterprises based on those ideas, and provide added value to society based on their independent initiative. Women entrepreneurs are those who are ready for confronting risk and have persistence to survive in a competitive business world. Hossain [7] states that the development of SMEs in developing countries is generally believed to be desirable, especially with regards to the perceived contribution of SMEs to decentralized job creation and output generation. SMEs constitute the dominant source ( 80 per cent) of industrial employment in Bangladesh, and about 90 per cent of the industrial units fall into this category. The actual performance of SMEs, however, varies depending on the relative economic efficiency, the macro-economic policy environment and the specific promotion policies pursued for their benefit. Mazumder and Choudhury [8] purposefully established the hypothesis that the performance of Bangladesh's SME sector is not good. Against such a backdrop, they explored the critical factors that impede growth and expansion of SMEs in the country. In this pursuit the authors have given their opinion that the existing policy environment is not conductive for SMEs to flourish, and that the factors must be removed and proper policy instruments are to be devised in order to leave the field level for the SME sector to grow. For this to happen, they advocate the concept of a new tool, that is, the incubators. And to manage the incubators, they suggest that there has been need for an Entrepreneurship Development Institute. Though the authors cited the overall problems of managing SMEs, they do not provide any specific problems for women entrepreneurs. They also provide limited suggestions for the removal of problems and development of SMEs.

Nawaz [9] analyzes various factors of rural women entrepreneurs in Bangladesh based on institutional theory that have three main pillars- regulative, cognitive and normative. Regulative factors refer to different rules of the Government that facilitate women entrepreneurship development in rural Bangladesh. Normative systems are typically imposing constraints on social behavior. But at the same time they enable social action. Cognitive factors associated with internal issues of women's life and their environmental interaction. Nawaz provides recommendations to improve women entrepreneurship in rural Bangladesh. Charantimath [10] argues that it is not always easy for women to find jobs that will be compatible with their family responsibilities and household chores. Thus, many women are attracted by the idea of self-employment in enterprises adjoining their house premises, with flexible hours, which allows them to take care of both home and business. Small-scale enterprises represent an important means of income for women in developing countries. They provide employment and income to alleviate poverty.

According to Kaushik [11] women have been taking an interest in recent year in self-employment. In the process of entrepreneurship, women have to face various problems and these problems, get doubled because of women's dual role as earner and homemakers. Siddiqui [12] points out some of the major problems of women entrepreneurs in India, which are - women's family obligations, gender inequality, problem of finance, low-level risk taking attitude, and the competition between women and men. The paper concludes that the problems of women entrepreneurs can be eradicated by appropriate training, incentives, encouragement, and motivation, social recognition of their entrepreneurial abilities, and family's moral support. Additionally, the tradition, customs, socio cultural values, ethics, motherhood, subordinates to husbands and men. The socio-cultural environment in which women are born and raised hinders them. Women in our country are considered physically weaker than man. Man thinks that women can't act though according to the situation. These are some peculiar problems that women are coming across while they jump into entrepreneurship.

The problems or factors that are mentioned by Siddiqui are quite similar to our country's condition. Women are as qualified as men to succeed as entrepreneurs, but they suffer two distinct disadvantages. First, there is the initial lack of confidence in their abilities. Years of accepting a subordinate status and strict role separation have left women lacking in their confidence to venture into new initiatives. Second, there is society's lack of confidence in women's ability. This is manifested in the family's unwillingness to finance a women's uncertain fate, in a banker's reluctance to take risk on projects set up by women, and in a general unwillingness to accept women as decision-makers or to stand as guarantors for loans to them. It is clear that special efforts are needed to promote and support women's entrepreneurship. As women entrepreneurship bring status to a women, on the other side their initiative helps to drive the wheel of the nation. This contributes to the nation's advancement. Without these womenfolk footsteps the journey toward progress is will remain incomplete. The women of Bangladesh have more social responsibility than their counterpart in the developed world. Given the complexities in the social environment and administrative structure, women's entrepreneurship in 
Bangladesh is more challenging.

\section{Methodology}

Even though, women are entering into business sector every day, they are still vulnerable and marginalized in the society. One of the indications of their marginalization is lack of information and statistics about the situation of women entrepreneurs. Due to lack of adequate information women entrepreneurs are excluded from development policies. It is difficult to address the issues of women entrepreneurs without having sufficient data on the situation of women entrepreneurs. The main research question of this study was whether women entrepreneurship has any socio-economic impact or not. The two sub-questions were (i) to what extent women entrepreneurship has a role in changing women's position in the family and (ii) to what extent women entrepreneurship has a role in economic development. The choice of research design depends mainly on the purpose for which the research is conducted. This was an exploratory research because there were not much relevant information about this topic was available and qualitative research approach was applied to explore information for this study. The study areas were Amberkhana and Lamabazar under Sylhet City Corporation where women entrepreneur of handloom industry were found. In this study, all female entrepreneurs of handloom industry under Sylhet City Corporation were considered as population and data were collected from the purposive sample drawn from the population. In-depth interview schedule had been conducted among 10 women entrepreneurs of Sylhet City Corporation. Since no comprehensive directory for women entrepreneurs in Sylhet was available, they were purposively selected for the study. At every stage of the selection of respondents, priority had given on the objectives of the study. The data for this study was collected through primary sources. At first a draft schedule was prepared considering the objectives of the study. Then the schedule was pre-tested in the selected area among a few women entrepreneur. The field trials helped in constructing the pre-coded responses to some questions and to improve the whole schedule. After making necessary modification and correction, the final schedule was prepared. The interview schedule was both close and open ended. Qualitative method was used for the analysis of results. After the collection of data, all of them were processed from first to last and then the data were categorized into themes. Therefore a thematic analysis was done for making interpretation.

\section{Results and Discussion}

Some factors have influenced over the change of different spans of women entrepreneur's life. They usually face problems and also overcome those to set them in a good social position in the society. The changes that have been taken place in their life through business may be narrated in this way. Mongoladebi (pseudo name), a 42 years old businesswoman, has become self-established since 2004. She was saying-

My business has changed my life. Had I not taken risks and started my own business, I might not have had any food for my daughter today. Overcoming the socio-economic obstacles of my own, Mongola I am now giving jobs to 6 more poor women which is commendable. But my story started horribly. I lost my husband 4 years after my marriage. I already had one baby girl. My in-laws were unwilling to bear the expenditures of mine and my daughter. I decided to start living in my parent's home in order to start a new life. My father tried a lot to get my remarried, but I refused every time. I knew the art of making muffler, shawl etc. I started selling them in initially. But when I started receiving orders from markets, I decided to go further and started my business by selling my ornaments. Though my father was not convinced about my decision, he helped me financially to start my business. It was a risky decision for me to invest all for a business. Nobody was convinced at me. Even the owner of the shop was not sure to give me the slot. I was confused about the economic success. I had to face a lot of problems starting my shop. Some local boys demanded extortion from me and started blathering about me

Now her father and relatives feel proud for her. Work values of initiative, achievement and respect are positively correlated with entrepreneurship. What she said was her respect and value increased more when she was able to successfully run her business. Still she has to face many problems. Local boys demand extortion for every single occasion, men often criticize her by saying that women don't know how to do business, some people especially men try to underrate her product. According to her, many women are withdrawing their business because of these problems. She doesn't want to quit her business which is only fulcrum of her earning.

Rumi Islam is another women entrepreneur who contributes to her family economically for the last 5 years. Near about 6 years ago her husband faced a major accident and luckily survived. Her husband was the only earning member and became handicapped. Then she was helpless at one point with no money. Other women who were self-dependent inspired her. She decided to do handloom business. Her brother-in-law assisted her initially. But her father-in-law was not supportive at all. He is very religious minded person and doesn't like the concept of daughter-in-law's going outside for earning money. When she told her father-in-law about that, he said-

Doing business is not a subject matter of women. 
Women are home's pride. People will blather about me if I send my daughter-in-law outside of the home for earning money. I convinced my family-in-law about my plan and execution process. Somehow I managed her and started to learn about handicraft industry. It was a tough period for me. I had some savings which was insufficient to start a business. I had to take loan several times with high interest rate from a local man. My father-in-law didn't allow me to apply for loans in any bank. Once I opened a shop, there was no looking back. I have a shop in Lamabazarpoint which is running fine. I alone looking after my husband, my business and the family as well

This statement of respondent shows the patriarchal mindset of our society. Our society is dominated by men. People here think that women should stay at home and raise children. Doing business and earning money is a man's job. That's why they don't want to support a struggling woman who is fighting for her own identity.

\section{She said-}

My family and two boys are everything for me. I tried to live with dignity. I was lucky and now I'm earning enough for my family

She said that Sylhet City is still not fully instrumental for women entrepreneurs. They have to face difficulties in every sphere of their work. They hardly ever allocated shops at the market. Banks are also not supportive at providing loans to women. She said that our society is still men dominated and for that reason women don't get access in every sector of business.

As women strive to gain funding and start their own business, execution what separates the dreamer from the doers. Amiye Marma is definitely belongs to the doers. She said-

As an entrepreneur, it is important to understand the difference between opinions and criticism. Many of us talked around the excuse of "oh, I'm not capable enough or it's not worth it" or "it won't work out". Women should change this kind of old thinking

Marma lives in Lamabazar, Monipuripara with her family. She learned how to make products like shawls, muffler, nokshikantha etc. She makes products at her home Five women work under her supervision. Her husband works as a middle man and sell her products to the market according to demand. He also brings order for her from the clients. She earns well enough to contribute to her family and pay wages of her workers.

Initial thinking behind her business was being self-dependent and to share the family responsibilities with her husband. She got inspiration from her family with full support. She is now successful and her family respects her. She can take part in every important matter of her family and her family members also obey her. She runs her work in her home so that she can manage the dual responsibilities of her family and business well. About opening a showroom in the market, she said that women have to face many difficulties while opening a showroom. Men don't want to help woman to progress. So she doesn't want to get herself engaged in extra trouble. She also said that she heard about the local boys harassing shop owners for extortions and due to this, many woman are quitting their business. Her business is going great in her home and right now she is not thinking about opening a showroom.

In Bangladesh, family type is very crucial to determine any person's role toward society. However, traditional family bonding is diminishing day by day, and as a result, nuclear families are forming at a high rate. In terms of women entrepreneurship, those who belong to a nuclear family are more engaged than those who belong to a joint family. There are still lots of expanded family in Sylhet City in comparison to the other urban cities. With the help of family members, it becomes easier for the women entrepreneurs to maintain dual responsibilities of family and business. Family members take care of the children when they are outside for their work. They get much needed help in crisis time which is instrumental. But there are also few women who think nuclear families are much better. They feel that there is lesser criticism and hindrance in small nuclear families. The extra responsibility of joint family is also a matter of concern for them.

Most of the respondents said that their business do not affects their roles as spouse, parent or homemaker very much. These women experienced very low levels of work-family conflict in their spousal or parental roles. Most of the time, their husbands or other family members encourage them to start and continue a business. About that a respondent commented -

I'm really blessed with supportive family members. They are always there to help me in any situation. Whenever I get busy with my work, my husband or father-in-law pick up my son from the school, also help him to study and sometimes feeds him in time

According to them if they face any problem in continuing business, their husbands and family members help them in this occasion. Crisis may arise at any steps of any work. One has to cope with the situation with the help of his well-wishers especially the role of the family is very important. From the study it is found that among the respondents most of the women entrepreneurs in Sylhet have got the support from their families. Among the entrepreneurs interviewed, most of them are middle-aged women. Among them, most of the women are Hindus. Considering the social structure of Sylhet, religion, norms and values are very influential in the life of people, especially for women. Most of the local people of Sylhet are regimented by religion and they are very conservative. But situation is gradually changing. A respondent among them commented that-

Earlier women and their family were not interested in engaging themselves for income generating activities. 
Now we have come out from the family and involved in income activities. We get enough support from our family members as well as from in-laws

It indicates that as women has started to contribute in the family expenses; the elder person's attitude towards the women has started changing. Now they don't think that women are to serve inside the house only. It helps to upgrade the position of women in a family.

Among women entrepreneurs interviewed, most of them are married. One is widow, one is divorcee and one is unmarried. These data indicate that after marriage, women are gradually becoming interested to be involved in business and entrepreneurial activities. Widows and divorced women also become self-reliant by the entrepreneurship. Most of the women said that they had to start the business in order to run their family. Many of them started their business at the situation when their family was passing through a financially crisis situation.

A respondent said that-

After my husband's death, there was no one who was able to bear the expense of me and my child. I thought of doing something and I don't know any other work except handicraft. So I started making mufflers and shawls and sold them to my neighbors. That's how I started my business. After observing my success, now my family members also support me to run my business.

After watching my sister-in-law earning, I realized that women can also contribute to the expense of family and that things improve the situation of women's in a family. By working, we don't need to be dependent on men for money anymore. So I started to work with her

Most of the respondent said that they wanted to be economically independence and their family also supported them to start their business. Most of the respondent said that-

The situation is changing; women empowerment has started to create its impact on the society and country

Their families support them always in any crisis situation whether it is about business or family affairs. Because of their husband's and in-laws support, they are being able to manage the dual responsibilities of their family and business life. About the source of capital, some of the women said that they had to sell their ornaments to start a business as their family was suffering from economic crisis. Some of them said that they worked in a shop for years and then they started their own business. Other respondents told that they took loan from their relatives or family members to start the business. They didn't try for bank loan because they were afraid of the interests and they had no knowledge about the process of apply for loans. At that time they were not aware about the NGO's who provide loans for small to medium sized enterprise (SME) with very little amount of interest. They were also not aware of the process to get a loan from banks. Some of them tried to take loans from bank but due to complexities, they couldn't proceed.

After starting the business their status has been increased in the family and in the society. Now they can enjoy freedom in their decision making and also can contribute in family decision making. Now they can also contribute in family economically. In recent years, huge changes occurred in the family expenditure structure where both male and female members of the family may agree to share family expenditures. The study finds that a maximum of believe that it will be much easier to continue their existing lifestyle if they equally contribute in family expenditures. Incomes of women entrepreneurs are used in several ways. Among the women entrepreneurs, most of the women expend their income in family expenditure which means they are contributing their family to a large extent. An inspiring matter is that all of the women entrepreneurs reinvest their income in their business, which implies that they are eager to expand their business. By contributing in the family expenditure, they are also being able to take part in the important family discussions and decisions.

About that one respondent said that women entrepreneurship is not only contributing to our economic development but also changes the decision making process in the family structure. Decision making in family affairs such as child care, child education, family expenditure, treatment of family members and buying/selling property are inherently vested upon male members of the family in our society. But women entrepreneurs develop the sense of participation in decision making. In most of the cases majority of the decisions (Child Care, Child Education, Family Expenditure, Treatment of Family Members \& Overall Family Matters, Buying/Selling Property and Pass Leisure Time) are taken jointly by the husband and wife. This also indicates that women entrepreneurship has satisfactory role in eradicating gender discrimination.

The impact of society is very crucial in every person's life, especially in women's way of living. Women entrepreneurs are not accepted in an ordinary manner in our society. As a result, they have to face changed behavior even from their family. The women entrepreneurs interviewed faced a changed behavior from their societies, whereas very few faced normal behavior. So it can be said that most women entrepreneurs of Sylhet City face different attitudes from their family members and relatives from when they engaged themselves in such activities. They had to face criticism from their relatives or neighbors and many people tried to provoke their family. The reason behind this kind of situation is in Bangladeshi women are always tried to be dominated by their male counterpart, even though women have equal rights as per constitutional rules.

It is found that because of not having enough scope for women to join a suitable job in Sylhet, they enter into 
business with a view to help their family and for their economic independence. The problems faced by the women entrepreneurs of Sylhet are maintaining the employees, getting raw materials, dealing with customers and in some cases friends and relatives make ill talk about the enterprise. Getting the startup capital is also a problem for many women entrepreneurs of Sylhet. Banks do not want to believe in women's word and women have to face many difficulties to apply for loans. But after starting the business successfully, this problem has been eliminated as other financial institutions also give loans to successful entrepreneurs. Yet, it is a matter of concern that women in Sylhet City are still engaged in traditional business. It is also found that while women's businesses generally created employment for men and women more or less equally, on the other hand men's businesses mainly employed men.

According to the respondent, Sylhet City is not very instrumental to women entrepreneurs. They have to face many problems when starting their business. They also have to face many kinds of difficulties running their business. Some major problems identified from the women entrepreneurs are given below-

- Most of the women entrepreneurs have no proper idea about the process of formal marketing. They supply their products to big shopping mall through middle man but most cases; it is difficult for them to have payment timely. Sometimes, they have to sell their product at lower price because they are women.

- They hardly ever allocated shops at the market place constructed or run by the city corporations or other local government bodies. Most of the time people do not want to rent their shops to a woman.

- There are no training opportunities for product diversification at the local level. Most of the women do not have idea about the product and design development. That is why they are confined with some traditional design and work.

- Most of the women entrepreneurs are unaware of the circulation of Bangladesh Bank on refinancing scheme for women SME. They are also not aware to get a loan from banks.

- Banks impose various conditions. In most cases, women entrepreneurs are unable to meet up their conditions. These conditions discourage women entrepreneurs to go to bank for a loan.

- The people working at various banks are not sensitized regarding women entrepreneurs. Current credit policies are male biased

- Local bully-boys (Bully-boys are those who are rough and threatening, especially one paid by someone to hurt or frighten other people) always excruciate women for extortions. Local authorities don't help them in this matter. Many women entrepreneurs had to move from the market because of this problem. Many entrepreneurs have quit their business because of the uncooperative behavior of the authorities and fellow male entrepreneurs.

- Businesses of Sylheti women entrepreneurs are most often home-based. They have dual responsibility of family and business. Hence, this dual responsibility is more easily achieved if women's businesses are close to their homes. Women entrepreneurs most often spend just as many hours in their businesses as men entrepreneurs; this means they face heavy workloads as they still have to attend to their household responsibilities after a long day of doing business.

\section{Conclusion}

There are some positive impacts of women entrepreneurship on socio-economic life of women in Sylhet of Bangladesh. They had to face lots of problem at the initial stage of their business establishment. But after overcoming that stage, they felt comfort in business life. The empowerment of women particularly decision making in different aspect of their life have been changed due to involvement in income generating activities. Their importance in family has also been increased for economic involvement into their family. Though they had huge positive impression over their family life and business also but many problems were faced in everyday life. Realization has gradually dawned on all concerned. None of a society cannot afford to waste half of its human resources by discrimination on grounds of gender. This increasing awareness on the part of the government has led to the adoption of national policies to facilitate a development process involving women in all spheres, particularly in economic activities focusing especially on entrepreneurship development. Women have now become aware of their socio-economic rights and have ventured to avail the opportunities initiated for them. A sustainable economy is a precondition for national growth and prosperity including institutionalization of a democratic system. It is impossible to achieve the target of a poverty-free society without incorporation of women in the mainstream economy. Considering the issue, a special emphasis has been given by the Government, donor agencies, NGOs, business community and all other relevant stakeholders through different interventions to ensure increased women's participation in formal economic sectors, especially in business and industry.

\section{REFERENCES}

[1] Bangladesh Bureau of Statistics (BBS) (2006) The 
Statistical Pocket of Book of Bangladesh (Dhaka, Bangladesh: Bangladesh Bureau of Statistics).

[2] Government of Bangladesh (GoB) (1998) The Constitution of the People's Republic of Bangladesh (Sydney, Australia: University of Technology, Faculty of Law, Australasian Legal Information Institute, Commonwealth Legal Information Institute; available at:

http://www.commonlii.org/bd/legis/const/2004/index.html

[3] Poverty Reduction Strategic Paper (2012) Ministry of Planning, Planning Commission, Government of Bangladesh

[4] Bangladesh Women Chamber of Commerce and Industry (BWCCI) (2008) / www.bwcci-bd.org.

[5] Giddens, Anthony(1990) The Conquences of Modernity, Standford University Press, USA

[6] Holt, D. H. (2000), Entrepreneurship: New Venture Creation, Fourth Indian Reprint, New Delhi: Prentice- Hall of India Private Limited.

[7] Hossain C. A. (2011), "Socio-Economic Impact of Women Entrepreneurship in Sylhet City, Bangladesh" working paper [12], Bangladesh Development Research centre,
U.S.A, July.

[8] Mazumder S A and Choudhury K (2001) “Jobs, Gender and Small Enterprises in Bangladesh: Factor Affecting Women Entrepreneurs in Small and Cottage Industries in Bangladesh", Geneva, Switzerland: International Labor Office (ILO) and Dhaka, Bangladesh: ILO Dhaka Office, SEED Working Paper No. 14 (February); available at: http://www.ilo.org/wcmsp5/groups/public/@ed_emp/@em p_ent/documents/publication/wcms_113774.pdf

[9] Nawaz, F. (2009), "Critical Factors of Women Entrepreneurship Development in Rural Bangladesh", Working Paper [5], Bangladesh Development Research center, U.S.A, May.

[10] Charantimath K (2012) Local Business Dynamics: Ground Realities and Policies

[11] Kaushik, S. (2013), "Challenges Faced by Women Entrepreneurs in India", International Journal of Management and Social Sciences Research,Vol.2 (2/February), pp. 6-8.

[12] Siddiqui, A. B. (2012), "Problems Encountered by Women Entrepreneurs in India”, International Journal of Applied Research \& Studies, Vol. I (II/Sept-Nov), pp. 1-11. 